\title{
Distribution of Phenolic Contents, Antidiabetic Potentials, Antihypertensive Properties, and Antioxidative Effects of Soursop (Annona muricata L.) Fruit Parts In Vitro
}

\author{
Stephen A. Adefegha, Sunday I. Oyeleye, and Ganiyu Oboh \\ Functional Foods and Nutraceutical Unit, Department of Biochemistry, Federal University of Technology, \\ PMB 704, Akure 340001, Nigeria
}

Correspondence should be addressed to Stephen A. Adefegha; saadefegha@futa.edu.ng

Received 29 July 2015; Accepted 26 November 2015

Academic Editor: Andrei Surguchov

Copyright (C) 2015 Stephen A. Adefegha et al. This is an open access article distributed under the Creative Commons Attribution License, which permits unrestricted use, distribution, and reproduction in any medium, provided the original work is properly cited.

\begin{abstract}
Soursop fruit has been used in folklore for the management of type-2 diabetes and hypertension with limited information on the scientific backing. This study investigated the effects of aqueous extracts $(1: 100 \mathrm{w} / \mathrm{v})$ of Soursop fruit part (pericarp, pulp, and seed) on key enzymes linked to type- 2 diabetes ( $\alpha$-amylase and $\alpha$-glucosidase) and hypertension [angiotensin-I converting enzyme (ACE)]. Radicals scavenging and $\mathrm{Fe}^{2+}$ chelation abilities and reducing property as well as phenolic contents of the extracts were also determined. Our data revealed that the extracts inhibited $\alpha$-amylase and $\alpha$-glucosidase and ACE activities dose-dependently. The effective concentration of the extract causing 50\% antioxidant activity $\left(\mathrm{EC}_{50}\right)$ revealed that pericarp extract had the highest $\alpha$ amylase $(0.46 \mathrm{mg} / \mathrm{mL}), \alpha$-glucosidase $(0.37 \mathrm{mg} / \mathrm{mL})$, and ACE $(0.03 \mathrm{mg} / \mathrm{mL})$ inhibitory activities while the seed extract had the least $[\alpha$-amylase $(0.76 \mathrm{mg} / \mathrm{mL}) ; \alpha$-glucosidase $(0.73 \mathrm{mg} / \mathrm{mL})$; and ACE $(0.20 \mathrm{mg} / \mathrm{mL})]$. Furthermore, the extracts scavenged radicals, reduced $\mathrm{Fe}^{3+}$ to $\mathrm{Fe}^{2+}$, and chelated $\mathrm{Fe}^{2+}$. The phenolic contents in the extracts ranged from 85.65 to $560.21 \mathrm{mg} / 100 \mathrm{~g}$. The enzymes inhibitory and antioxidants potentials of the extracts could be attributed to their phenolic distributions which could be among the scientific basis for their use in the management of diabetes and hypertension. However, the pericarp appeared to be most promising.
\end{abstract}

\section{Introduction}

About 382 million people were estimated to be living with diabetes mellitus (DM) globally, with an alarming projection of 471 million people with the disease by the year 2035 [1]. Type-2 diabetes mellitus accounts for over ninety percent of all cases of diabetes mellitus (DM), in both developed and developing countries. It is characterized by hyperglycemia resulting from defects in insulin secretion, insulin insensitivity, or both [2]. Decreasing hyperglycemia represents a major therapeutic approach towards the management of type- 2 diabetes. However, the inhibition of key enzymes ( $\alpha$ amylase and $\alpha$-glucosidase) involved in the hydrolysis of starch and absorption of glucose may confer nutraceutical solution towards the management of the diseases. Some drugs presently used (acarbose and miglitol) reduce blood glucose level but with accompanied severe pharmacological side effects $[3,4]$.

One of the long term complications of diabetes is hypertension [5]. Angiotensin-I converting enzyme (ACE) is a zinc metallopeptidase that converts angiotensin-I to angiotensin-II, a potent vasoconstrictor, and breaks down bradykinin, a vasodilator [6]. Inhibition of ACE is considered a useful therapeutic approach in the management of hypertension in both diabetic and nondiabetic patients [6]. Furthermore, ACE inhibitors have been reported to reduce the risk of type-2 diabetes in nondiabetic patients at baseline; bradykinin enhances the responsiveness of both muscle fiber and adipocytes to insulin [6].

Soursop (Annona muricata L.) otherwise known as graviola or guanabana is an edible tropical fruit tree that is widely cultivated across regions of the world [7]. Soursop fruit is 
specially known for its commercial value in the production of juice, candy, and sherbets [8]. The roots of these species are used in traditional medicine due to their antiparasitic and pesticidal properties. Intensive chemical investigations of the leaves and seeds of this plant have resulted in the isolation of a great number of bioactive compounds which were found to display interesting biological including antitumor, cytotoxicity, and antiparasitic and pesticidal properties $[8,9]$. Soursop fruit has been reported in folklore medicine for the prevention/management of type- 2 diabetes and hypertension with little or no biochemical basis. This work was designed to investigate the effect of Soursop fruit parts (pericarp, pulp, and seed) extracts on key enzymes ( $\alpha$-amylase and $\alpha$ glucosidase) linked with type- 2 diabetes and [angiotensin-I converting enzyme (ACE)] hypertension. The distribution of phenolic contents and antioxidant properties of the Soursop fruit part extracts were subsequently assessed.

\section{Materials and Methods}

2.1. Sample Collection and Extraction. Soursop fruits were collected from botanical garden at the Federal University of Technology, Akure, Nigeria. Authentication of the fruit was carried out at the Department of Crop, Soil, and Pest Management, Federal University of Technology, Akure.

2.2. Sample Preparation. The fruits were sorted out and washed under running water to remove dirt. Thereafter, the fruits were separated into seeds, pulp, and fruit peels using table knife. They were chopped into small pieces by table knife, air-dried, and milled into a fine powder.

2.3. Preparation of the Extracts. The aqueous extracts were prepared by soaking $100 \mathrm{~g}$ of the powdered samples into $500 \mathrm{~mL}$ of distilled water for $24 \mathrm{~h}$ and filtered thereafter using Whatman filter paper. The filtrate was further spun in the centrifuge at $4000 \times \mathrm{g}$ to obtain clear supernatants which were refrigerated and freeze-dried with the aid of freeze-drier. The dried powder was reconstituted in distilled water $(1: 100 \mathrm{w} / \mathrm{v})$ and stored in the refrigerator for further analysis [10].

2.4. Reagents. Except otherwise stated, all chemicals used were of analytical grade. Glass distilled water was used.

2.5. $\alpha$-Amylase Inhibition Assay. Appropriate dilutions of the extracts $(500 \mu \mathrm{L})$ in $0.02 \mathrm{M}$ sodium phosphate buffer $(\mathrm{pH}$ 6.9 with $0.006 \mathrm{M} \mathrm{NaCl}$ ) were added to $0.5 \mathrm{mg} / \mathrm{mL}$ of $\mathrm{Hog}$ pancreatic $\alpha$-amylase (EC 3.2.1.1) and subsequently incubated at $25^{\circ} \mathrm{C}$ for $10 \mathrm{~min}$. Then, $500 \mu \mathrm{L}$ of $1 \%$ starch solution in $0.02 \mathrm{M}$ sodium phosphate buffer ( $\mathrm{pH} 6.9$ with $0.006 \mathrm{M} \mathrm{NaCl}$ ) was added to each tube. The reaction mixture was incubated at $25^{\circ} \mathrm{C}$ for $10 \mathrm{~min}$ and stopped with $1.0 \mathrm{~mL}$ of dinitrosalicylic acid (DNSA) color reagent. Thereafter, the mixture was incubated in a boiling bath for $5 \mathrm{~min}$ and cooled to room temperature. The reaction mixture was further diluted with $10 \mathrm{~mL}$ of distilled water and the absorbance was read at $540 \mathrm{~nm}$. The inhibitory effect of the extracts was calculated and expressed as percentage inhibition while acarbose was used as control [11].
2.6. $\alpha$-Glucosidase Inhibition Assay. Fifty microliters of appropriate dilution of the extracts was added to $100 \mu \mathrm{L}$ of the $\alpha$-glucosidase solution $(1.0 \mathrm{U} / \mathrm{mL})$ in $1.0 \mathrm{M}$ phosphate buffer (pH 6.9) and incubated at $25^{\circ} \mathrm{C}$ for $10 \mathrm{~min}$. Fifty microliters of $5 \mathrm{mM}$ p-nitrophenyl- $\alpha$-D-glucopyranoside solution in $0.1 \mathrm{M}$ phosphate buffer ( $\mathrm{pH}$ 6.9) was subsequently added. The reaction mixture was incubated at $25^{\circ} \mathrm{C}$ for $5 \mathrm{~min}$ and the absorbance was read at $405 \mathrm{~nm}$ in the spectrophotometer. The $\alpha$-glucosidase inhibitory activity of the extract was calculated and expressed as percentage inhibition while acarbose was used as control [12].

2.7. Angiotensin-I Converting Enzyme (ACE) Inhibition Assay. Fifty microliters $(50 \mu \mathrm{L})$ of appropriate dilution of the extracts and ACE solution $(50 \mu \mathrm{L}$ and $4 \mathrm{mU})$ was incubated at $37^{\circ} \mathrm{C}$ for $15 \mathrm{~min}$. The enzymatic reaction was initiated by adding $150 \mu \mathrm{L}$ of $8.33 \mathrm{mM}$ of the substrate Bz-Gly-His-Leu in $125 \mathrm{mM}$ Tris- $\mathrm{HCl}$ buffer ( $\mathrm{pH} \mathrm{8.3)}$ to the mixture. After incubation for $30 \mathrm{~min}$ at $37^{\circ} \mathrm{C}$, the reaction mixture was arrested by adding $250 \mu \mathrm{L}$ of $1 \mathrm{M} \mathrm{HCl}$. The Gly-His bond was then cleaved and the Bz-Gly produced by the reaction was extracted with $1.5 \mathrm{~mL}$ ethyl acetate. Thereafter the mixture was spun to separate the ethyl acetate layer. Then $1 \mathrm{~mL}$ of the ethyl acetate layer was transferred to a clean test tube and evaporated. The residue was redissolved in distilled water and its absorbance was measured at $228 \mathrm{~nm}$. The ACE inhibitory activity was expressed as percentage inhibition while captopril was used as control [13].

2.8. Free Radical Scavenging Ability. The free radical scavenging ability of the extracts against DPPH (1,1-diphenyl-2picrylhydrazyl) free radical was evaluated according to the method described by Gyamfi et al., 1999 [14]. Appropriate dilution of the extracts $(1 \mathrm{~mL})$ was mixed with $1 \mathrm{~mL}$ of $0.4 \mathrm{mM}$ $\mathrm{DPPH}$ in methanolic solution. The mixture was left in the dark for $30 \mathrm{~min}$ and the absorbance was measured at $516 \mathrm{~nm}$. The DPPH free radical scavenging ability was subsequently calculated.

2.9. Total Antioxidant Power. Total antioxidant power of the extracts was assessed using the ABTS radical model as described by $\mathrm{Re}$ et al., 1999 [15]. The ABTS radical was generated by reacting $7 \mathrm{mmol} / \mathrm{L}$ of ABTS aqueous solution with $2.45 \mathrm{mmol} / \mathrm{L}$ of $\mathrm{K}_{2} \mathrm{~S}_{2} \mathrm{O}_{8}$ solution in the dark for $16 \mathrm{~h}$ and adjusting the Abs734 nm to 0.700 with ethanol. Two hundred microliters of the appropriate dilution of the sample extracts was added to $2.0 \mathrm{~mL}$ ABTS radical solution and the absorbance was measured at $734 \mathrm{~nm}$ after $15 \mathrm{~min}$. The Trolox equivalent antioxidant capacity was subsequently calculated.

2.10. Hydroxyl (OH) Radical Scavenging Assay. The method of Halliwell and Gutteridge, 1981 [16], was used to determine the ability of the extracts to prevent $\mathrm{Fe}^{2+} / \mathrm{H}_{2} \mathrm{O}_{2}$ induced decomposition of deoxyribose. The extract $0-100 \mu \mathrm{L}$ was added to a reaction mixture containing $120 \mu \mathrm{L}$ of $20 \mathrm{mM}$ deoxyribose, $400 \mu \mathrm{L}$ of $0.1 \mathrm{M}$ phosphate buffer, and $40 \mu \mathrm{L}$ of $500 \mu \mathrm{M} \mathrm{FeSO}_{4}$, and the volume was made up to $800 \mu \mathrm{L}$ with distilled water. The reaction mixture was incubated at $37^{\circ} \mathrm{C}$ for $30 \mathrm{~min}$ and the reaction was then stopped by 
the addition of $0.5 \mathrm{~mL}$ of $28 \%$ trichloroacetic acid. This was followed by addition of $0.4 \mathrm{~mL}$ of $0.6 \%$ thiobarbituric acid solution. The tubes were subsequently incubated in boiling water for $20 \mathrm{~min}$. The absorbance was measured at $532 \mathrm{~nm}$ in a spectrophotometer and the $\mathrm{OH}$ scavenging ability was subsequently calculated.

2.11. Determination of Reducing Property. The reducing property of the extracts was determined by assessing the ability of the sample extract to reduce $\mathrm{FeCl}_{3}$ solution as described by Oyaizu, 1986 [17]. $2.5 \mathrm{~mL}$ aliquot was mixed with $2.5 \mathrm{~mL}$ of $200 \mathrm{mM}$ sodium phosphate buffer ( $\mathrm{pH} 6.6$ ) and $2.5 \mathrm{~mL}$ of $1 \%$ potassium ferricyanide. The mixture was incubated at $50^{\circ} \mathrm{C}$ for $20 \mathrm{~min}$. And then $2.5 \mathrm{~mL}$ of $10 \%$ trichloroacetic acid was added. This mixture was centrifuged at $650 \mathrm{rpm}$ for $10 \mathrm{~min}$. $5 \mathrm{~mL}$ of the supernatant was mixed with an equal volume of water and $1 \mathrm{~mL}$ of $0.1 \%$ ferric chloride. The absorbance was measured at $700 \mathrm{~nm}$. The ferric reducing antioxidant property was subsequently calculated.

2.12. $\mathrm{Fe}^{2+}$ Chelation Assay. The $\mathrm{Fe}^{2+}$ chelating ability of the extracts was determined using the method of Minotti and Aust, 1987 [18], with a slight modification by Puntel et al., 2005 [19]. Freshly prepared $500 \mu \mathrm{M} \mathrm{FeSO}_{4}(150 \mu \mathrm{L})$ was added to a reaction mixture containing $168 \mu \mathrm{L}$ of $0.1 \mathrm{M}$ Tris- $\mathrm{HCl}$ ( $\mathrm{pH}$ 7.4), $218 \mu \mathrm{L}$ saline, and sample extracts $(0-25 \mu \mathrm{L}$ ). The reaction mixture was incubated for $5 \mathrm{~min}$, before the addition of $13 \mu \mathrm{L}$ of $0.25 \% 1,10$-phenanthroline (w/v). The absorbance was subsequently measured at $510 \mathrm{~nm}$ in a spectrophotometer. The $\mathrm{Fe}^{2+}$ chelating ability was subsequently calculated.

2.13. Determination of Total Phenol Content. The total phenol content was determined according to the method of Singleton et al., 1999 [20]. Briefly, appropriate dilutions of the extracts were oxidized with $2.5 \mathrm{~mL}$ of $10 \%$ Folin-Ciocalteu's reagent $(\mathrm{v} / \mathrm{v})$ and neutralized by $2.0 \mathrm{~mL}$ of $7.5 \%$ sodium carbonate. The reaction mixture was incubated for $40 \mathrm{~min}$ at $45^{\circ} \mathrm{C}$ and the absorbance was measured at $765 \mathrm{~nm}$ in the spectrophotometer. The total phenol content was subsequently calculated as gallic acid equivalent.

2.14. Determination of Total Flavonoid Content. The total flavonoid content was determined using a slightly modified method reported by Meda et al., 2005 [21]. Briefly $0.5 \mathrm{~mL}$ of appropriately diluted extracts was mixed with $0.5 \mathrm{~mL}$ of methanol, $50 \mu \mathrm{L}$ of $10 \% \mathrm{AlCl}_{3}, 50 \mu \mathrm{L}$ of $1 \mathrm{M}$ potassium acetate, and $1.4 \mathrm{~mL}$ of water and allowed to incubate at room temperature for $30 \mathrm{~min}$. The absorbance of the reaction mixture was subsequently measured at $415 \mathrm{~nm}$; the total flavonoid content was subsequently calculated.

2.15. Data Analysis. The results of three (3) replicate experiments were pooled and expressed as mean \pm standard deviation (SD). One-way analysis of variance (ANOVA) was used to analyse the mean and the post hoc treatment was performed using Duncan multiple test [22]. Significance was accepted at $P \leq 0.05$. EC $_{50}$ (extract concentration causing $50 \%$ antioxidant activity) was determined using nonlinear

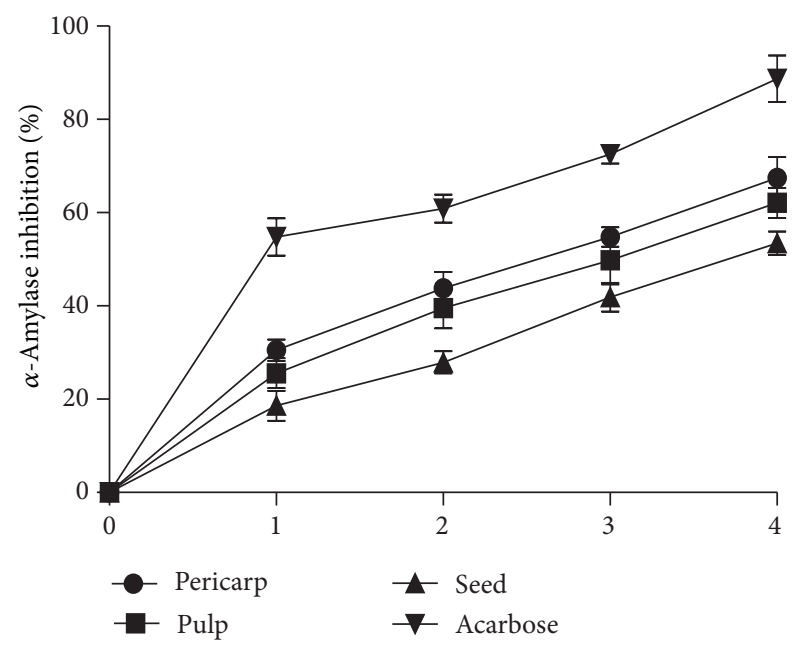

FIgure 1: Percentage of $\alpha$-glucosidase inhibition by extracts from Soursop fruit part and acarbose. The concentrations of the extract used for the plot are $0.00,0.20,0.40,0.6$, and $0.80 \mathrm{mg} / \mathrm{mL}$. The concentrations of the acarbose used for the plot are $0.00,10.00,30.00$, and $40.00 \mu \mathrm{g} / \mathrm{mL}$. Values represent mean of standard deviation of triplicate readings.

regression analysis with Graph Pad Prism version 5.00 for Windows.

\section{Results}

The in vitro $\alpha$-amylase inhibitory effect of the aqueous extracts of different parts of Soursop fruit is presented in Figure 1. The result showed that all the extracts inhibited $\alpha$ amylase activity in a concentration dependent manner $(0-$ $0.8 \mathrm{mg} / \mathrm{mL}$ ). Nevertheless, the $\mathrm{EC}_{50}$ values (Table 1) showed that the pericarp extract $\left(\mathrm{EC}_{50}=0.46 \pm 0.03 \mathrm{mg} / \mathrm{mL}\right) \mathrm{had}$ the highest inhibitory effect but lower inhibitory effect when compared to acarbose $\left(\mathrm{IC}_{50}=9.51 \pm 0.11 \mu \mathrm{g} / \mathrm{mL}\right)$, while that of the seed $\left(\mathrm{EC}_{50}=0.76 \pm 0.03 \mathrm{mg} / \mathrm{mL}\right)$ had the least. Similarly, the in vitro $\alpha$-glucosidase inhibitory effect of the acarbose and the extracts of different parts of Soursop fruit is presented in Figure 2. The result showed that all the extracts and acarbose inhibited $\alpha$-glucosidase activity in a concentration dependent manner. Nevertheless, the pericarp extract $\left(\mathrm{EC}_{50}=0.37 \pm 0.03 \mathrm{mg} / \mathrm{mL}\right)$ had the highest inhibitory effect on $\alpha$-glucosidase activity but lower inhibitory effect when compared to acarbose $(12.97 \mu \mathrm{g} / \mathrm{mL})$ drug (Table 1). The in vitro ACE inhibitory effect of the aqueous extracts of different parts of Soursop fruit is presented in Figure 3. The result showed that all the extracts inhibited ACE activity in a concentration dependent manner $(0-0.25 \mathrm{mg} / \mathrm{mL})$. However, the $\mathrm{EC}_{50}$ values (Table 1) showed that the pericarp extracts $\left(\mathrm{EC}_{50}=0.03 \pm 0.01 \mathrm{mg} / \mathrm{mL}\right)$ had the highest ACE inhibitory effect when compared to the pulp $\left(\mathrm{EC}_{50}=0.14 \pm 0.02 \mathrm{mg} / \mathrm{mL}\right.$ ) and seeds $\left(\mathrm{EC}_{50}=0.20 \pm 0.03 \mathrm{mg} / \mathrm{mL}\right)$ extracts. However, there was no significant $(P>0.05)$ difference between the pulp and the seed. Captopril had the highest ACE inhibitory effect compared to the entire sample extract with $\mathrm{IC}_{50}$ value of $0.13 \mu \mathrm{g} / \mathrm{mL}$. 
TABLE 1: $\mathrm{EC}_{50}$ values for $\alpha$-amylase, $\alpha$-glucosidase, and ACE inhibitory properties and radicals (DPPH and $\mathrm{OH}$ ) scavenging and Fe ${ }^{2+}$ chelating abilities of aqueous extracts of different parts of Soursop fruit $(\mathrm{mg} / \mathrm{mL})$ and standards $(\mu \mathrm{g} / \mathrm{mL})$.

\begin{tabular}{|c|c|c|c|c|c|}
\hline & Pericarp & Pulp & Seed & Acarbose & Captopril \\
\hline$\alpha$-Amylase & $0.46 \pm 0.03^{\mathrm{a}}$ & $0.54 \pm 0.03^{b}$ & $0.76 \pm 0.03^{c}$ & $12.97 \pm 0.11^{\mathrm{a}}$ & - \\
\hline$\alpha$-Glucosidase & $0.37 \pm 0.03^{\mathrm{a}}$ & $0.51 \pm 0.07^{\mathrm{b}}$ & $0.73 \pm 0.05^{c}$ & $9.51 \pm 1.09^{\mathrm{a}}$ & - \\
\hline ACE & $0.03 \pm 0.01^{\mathrm{a}}$ & $0.14 \pm 0.02^{\mathrm{b}}$ & $0.20 \pm 0.03^{\mathrm{c}}$ & - & $0.13 \pm 0.02^{\mathrm{a}}$ \\
\hline DPPH radical & $0.87 \pm 0.01^{\mathrm{a}}$ & $2.24 \pm 0.07^{\mathrm{b}}$ & $5.44 \pm 0.04^{c}$ & - & - \\
\hline $\mathrm{OH}$ radical & $0.37 \pm 0.01^{\mathrm{a}}$ & $0.46 \pm 0.03^{\mathrm{b}}$ & $2.25 \pm 0.14^{\mathrm{c}}$ & - & - \\
\hline $\mathrm{Fe}^{2+}$ chelation & $0.39 \pm 0.06^{\mathrm{a}}$ & $1.78 \pm 0.16^{\mathrm{b}}$ & $3.21 \pm 0.05^{\mathrm{c}}$ & - & - \\
\hline
\end{tabular}

Values represent means \pm standard deviation of triplicate readings.

Values with the same superscript letter along the same row are not significantly different $(P>0.05)$.

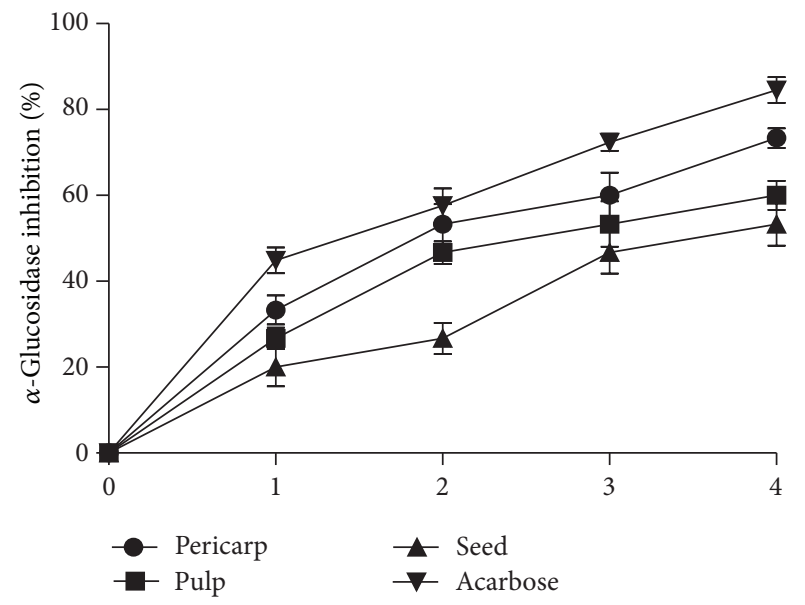

Figure 2: Percentage of $\alpha$-glucosidase inhibition by extracts from Soursop fruit part and acarbose. The concentrations of the extract used for the plot are $0.00,0.20,0.40,0.6$, and $0.80 \mathrm{mg} / \mathrm{mL}$. The concentrations of the acarbose used for the plot are $0.00,10.00,30.00$, and $40.00 \mu \mathrm{g} / \mathrm{mL}$. Values represent mean of standard deviation of triplicate readings.

Figure 4 showed the result of the DPPH free radical scavenging abilities of the extracts of Soursop fruit (pericarp, pulp, and seed). The results showed that all the extracts scavenged DPPH radical in concentration dependent manner (0-4.0 mg/mL). As shown in Table 1, extract of the pericarp had the highest $\mathrm{DPPH}$ radical scavenging ability $\left(\mathrm{EC}_{50}=\right.$ $0.87 \pm 0.01 \mathrm{mg} / \mathrm{mL})$, when compared to the pulp $\left(\mathrm{EC}_{50}=\right.$ $2.24 \pm 0.07 \mathrm{mg} / \mathrm{mL})$ and seed $\left(\mathrm{EC}_{50}=5.44 \pm 0.04 \mathrm{mg} / \mathrm{mL}\right)$ extracts. Figure 5 revealed the result of the ABTS free radical scavenging abilities of the studied extracts. All the extracts scavenged ABTS free radical. The pericarp extract (34.9 \pm $2.1 \mathrm{mmol}$ TEAC/100 g) had the highest scavenging ability while the seed $(8.3 \pm 2.6 \mathrm{mmol}$ TEAC/100 g) had the least. Furthermore, Figure 6 depicted the result of the hydroxyl $(\mathrm{OH})$ radical scavenging ability of the extracts of Soursop fruit (pericarp, pulp, and seed). All the extracts significantly $(P<0.05)$ scavenged $\mathrm{OH}$ radical in concentration dependent manner $(0-0.87 \mathrm{mg} / \mathrm{mL})$. The extract of the pericarp had the highest $\mathrm{OH}$ radical scavenging ability $(0.37 \pm 0.01 \mathrm{mg} / \mathrm{mL})$, while that of the seed had the least $(2.25 \pm 0.14 \mathrm{mg} / \mathrm{mL})$.

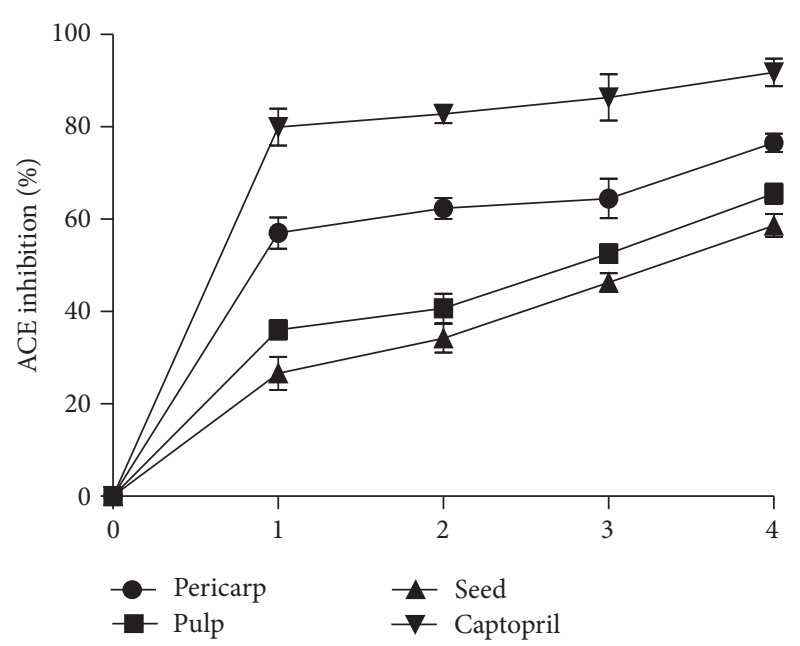

Figure 3: Angiotensin-I converting enzyme (ACE) inhibition by extracts from Soursop fruit part and captopril. The concentrations of the extract for the plot are $0.00,0.05,0.10,0.20$, and $0.25 \mathrm{mg} / \mathrm{mL}$. The concentrations of captopril used for the plot are $0.00,1.50,2.50$, 5.00 , and $6.50 \mu \mathrm{g} / \mathrm{mL}$. Values represent mean of standard deviation of triplicate readings.

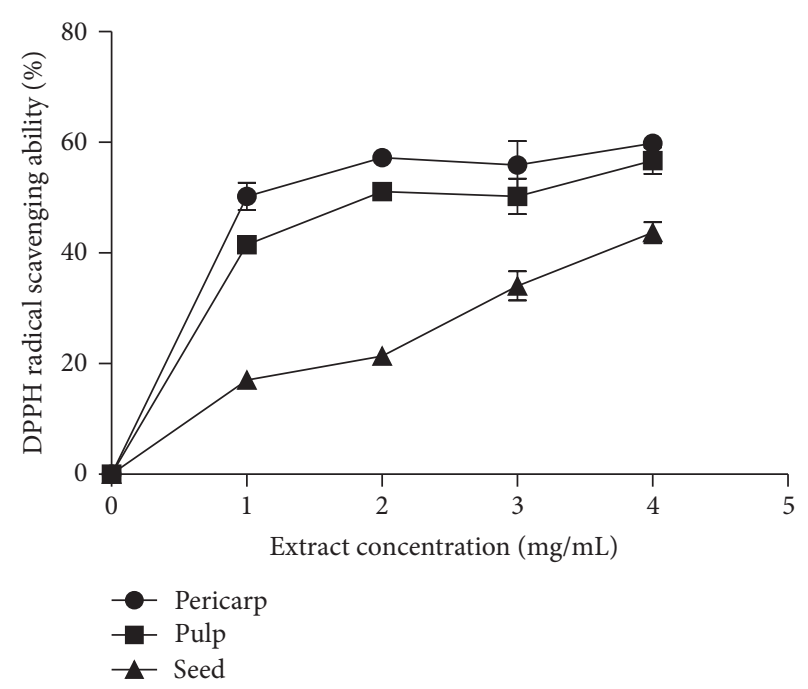

FIGURE 4: DPPH radical scavenging ability (\%) of the aqueous extracts of the pericarp, pulp, and seed of Soursop fruit. 


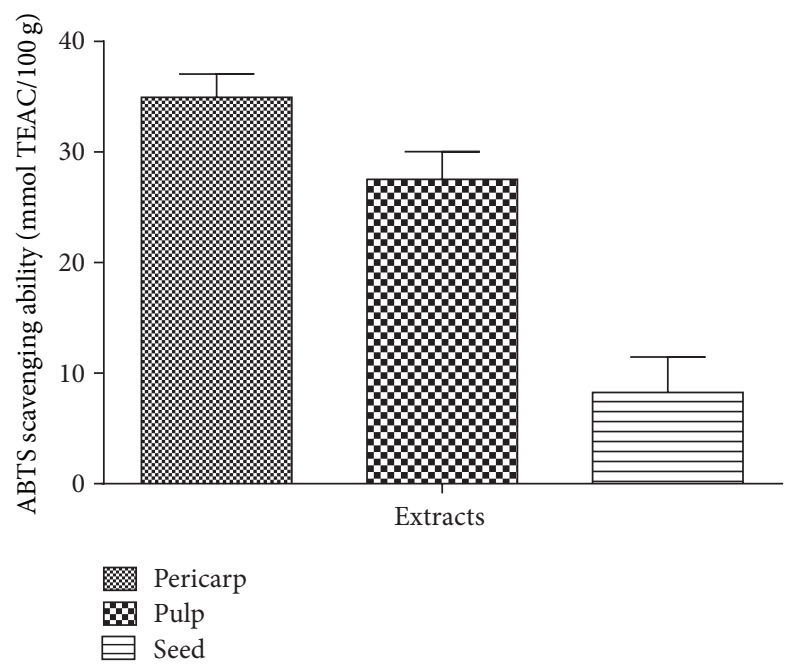

FIGURE 5: ABTS radical scavenging ability of the aqueous extracts of the pericarp, pulp, and seed of Soursop fruit.

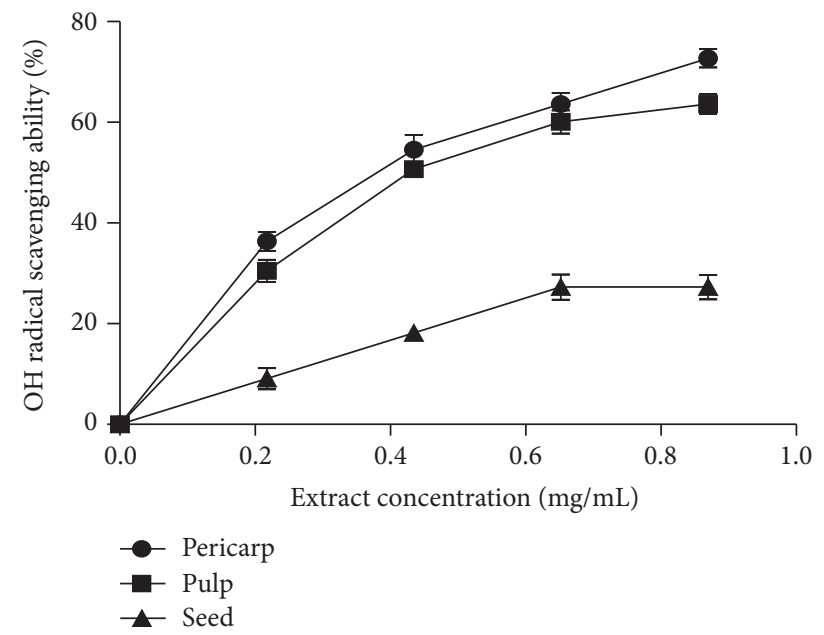

Figure 6: Hydroxyl $(\mathrm{OH})$ radical scavenging ability (\%) of the aqueous extracts of the pericarp, pulp, and seed of Soursop fruit.

Figure 7 showed the result of the $\mathrm{Fe}^{2+}$ chelating ability of the extracts of Soursop fruit part (pericarp, pulp, and seed). The extracts chelated $\mathrm{Fe}^{2+}$ in concentration dependent manner $(0-1.0 \mathrm{mg} / \mathrm{mL})$ and the pericarp extracts $\left(\mathrm{EC}_{50}=0.39 \pm\right.$ $0.06 \mathrm{mg} / \mathrm{mL}$ ) had the highest $\mathrm{Fe}^{2+}$ chelating ability, while the seed had the least $\left(\mathrm{EC}_{50}=3.21 \pm 0.05 \mathrm{mg} / \mathrm{mL}\right)$. The result of the ferric reducing antioxidant property of the Soursop fruit (pericarp, pulp, and seed) extract is presented in Table 2. The results showed that the reducing property of extracts ranged from $45.70 \pm 4.28 \mathrm{mg} \mathrm{AAE} / 100 \mathrm{~g}$ (seed) to $637.10 \pm 9.11 \mathrm{mg}$ AAE $/ 100 \mathrm{~g}$ (pericarp).

Table 2 showed the total phenol and flavonoid contents of the extracts from the different parts of Soursop fruit understudied. The result showed that the total phenol content of the extract ranged from $50.51 \pm 3.21 \mathrm{mg} / 100 \mathrm{~g}$ (seed) to $560.21 \pm 6.22 \mathrm{mg} / 100 \mathrm{~g}$ (pericarp) while the total flavonoid contents ranged from $85.65 \pm 7.63 \mathrm{mg} / 100 \mathrm{~g}$ (seed) to
TABLE 2: Total phenol and flavonoid contents and ferric reducing antioxidant property (FRAP) of aqueous extracts of different parts of Soursop fruit $(\mathrm{mg} / 100 \mathrm{~g})$.

\begin{tabular}{lccc}
\hline & Pericarp & Pulp & Seed \\
\hline Total phenol & $560.21 \pm 6.22^{\mathrm{a}}$ & $430.29 \pm 10.61^{\mathrm{b}}$ & $50.51 \pm 3.21^{\mathrm{c}}$ \\
Total flavonoid & $275.45 \pm 10.01^{\mathrm{a}}$ & $100.01 \pm 8.53^{\mathrm{b}}$ & $85.65 \pm 7.63^{\mathrm{c}}$ \\
FRAP & $637.10 \pm 9.11^{\mathrm{a}}$ & $381.72 \pm 8.22^{\mathrm{b}}$ & $45.70 \pm 4.28^{\mathrm{c}}$ \\
\hline
\end{tabular}

Values represent means \pm standard deviation of triplicate readings.

Values with the same superscript letter along the same row are not significantly different $(P>0.05)$.

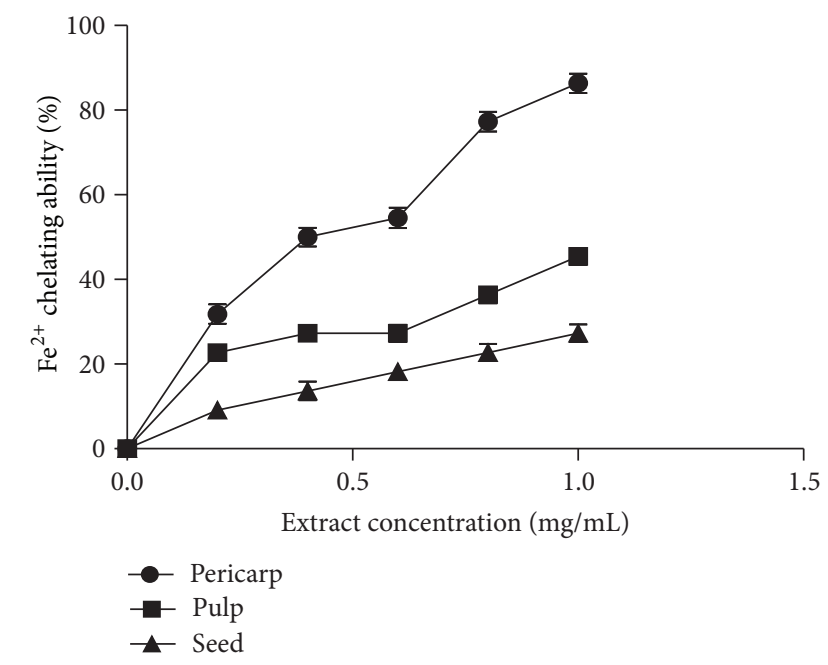

Figure 7: $\mathrm{Fe}^{2+}$ chelating ability (\%) of the aqueous extracts of the pericarp, pulp, and seed of Soursop fruit.

$275.45 \pm 10.01 \mathrm{mg} / 100 \mathrm{~g}$ (pericarp). Overall, pericarp extract had the highest total phenol and flavonoid content followed by the pulp and the seed had the least.

\section{Discussion}

The observed inhibitory effect of the Soursop fruit part extracts on $\alpha$-amylase and $\alpha$-glucosidase activities in vitro suggests the possible mechanism by which Soursop fruit parts exert their antidiabetic effect and may be part of the underlying basis for their folkloric use in the management/treatment of diabetes. Several studies have revealed that $\alpha$-amylase and $\alpha$-glucosidase activity have a great influence on blood glucose level and their inhibition could significantly reduce the postprandial increase of blood glucose [23]. It has also been established that reducing postprandial hyperglycemia is an important strategy towards type-2 management [24]. From this study, the pericarp of the fruit which had the highest total phenol and flavonoid content exhibited the highest $\alpha$-amylase and $\alpha$-glucosidase inhibitory effects. This is consistent with earlier studies where $\alpha$-amylase and $\alpha$ glucosidase inhibitory effect of plant foods are attributed to their phenolic constituents [25-27]. In addition, the fact that Soursop extracts significantly $(P<0.05)$ inhibited $\alpha$ glucosidase more than $\alpha$-amylase is of therapeutic importance at preventing the unpleasant side effects associated with 
strong synthetic $\alpha$-amylase inhibitors, such as acarbose, and also agrees with previous studies that plant phenolic-rich extract inhibited $\alpha$-glucosidase activity better than $\alpha$-amylase activity [26, 28].

Although inhibitors of ACE activity are antihypertensive agents, they have been reported to reduce the risk of developing of type- 2 diabetes $[6,28]$. ACE inhibitors stimulate the release of bradykinin which, in turn, enhances the responsiveness of both muscle fiber and adipocytes to insulin utilization [6]. From the result, a strong correlation between the ACE inhibitory effects of the Soursop fruit extracts and the phenolic content was observed. The ability of the plant bioactive compounds such as phenolics could inhibit ACE activity [29-31]. It is proposed that phenolic phytochemicals showed a structure-function relationship in inhibiting ACE activity by chelating the active site zinc ion or inducing the formation of hydrogen bridges between the active site amino acid residues and the phenols [32]. This study showed strong correlation between the ACE inhibitory effect and the phenolic contents, as evidenced by the efficacy of the fruit pericarp with the highest phenolic contents. In line with increased interest in natural products as alternative to synthetic drugs, it is believed that these extracts would have little or no side effects when compared to these synthetic ACE inhibitor drugs such as captopril.

One of the risk factors in type- 2 diabetes mellitus and its cardiovascular complication (hypertension) is oxidative stress. Oxidative stress has been reported to play a vital role in the etiology and development of type- 2 diabetes and hypertension. Free radicals induced oxidative damage of pancreatic $\beta$-cells has been implicated in impaired insulin production/function, a major risk factor of diabetes development [33]. Also, oxidative damage to endothelia cell of the blood vessel could compromise the elasticity of the vessel resulting in hypertension or some other cardiovascular complications [34]. Thus combating oxidative stress could be a practical way to ensure holistic management of type2 diabetes and hypertension. Therefore, it is imperative to investigate the antioxidant properties of Soursop fruit extracts, which have been reported in folklore medicine to be potent in the management of several diseases including diabetes and hypertension.

Polyphenolic compounds have shown antioxidant properties by reduction of $\mathrm{Fe}^{3+}$ to $\mathrm{Fe}^{2+}$, chelation of $\mathrm{Fe}$, and mopping of radicals [26]. ABTS radical, a protonated radical, have characteristic absorbance maxima at $734 \mathrm{~nm}$ which decrease with the scavenging of the proton radicals [35], while the DPPH radical scavenging ability is through hydrogen ion donating ability [36]. This study showed that the extracts were able to scavenge (DPPH and ABTS) free radicals. The pericarp extract had the highest scavenging abilities as well as the highest total phenol and flavonoid contents.

Free radicals are capable of inducing oxidative damages in biomolecules via several reaction processes. One of such reactions is the Fenton reaction in which degradation of deoxyribose is initiated through $\mathrm{Fe}^{2+}$ catalyzed hydrogen peroxide $\left(\mathrm{H}_{2} \mathrm{O}_{2}\right)$ decomposition to produce $\mathrm{OH}$ radicals [37]. The antioxidant properties of the Soursop fruit part extracts can also be measured by the ability to prevent degradation of deoxyribose via scavenging of hydroxyl $(\mathrm{OH})$ radical and chelation of transition metals such as $\mathrm{Fe}^{2+}$. As observed in this study, $\mathrm{OH}$ radical scavenging and $\mathrm{Fe}^{2+}$ chelating abilities of the Soursop fruit parts (pericarp, pulp, and seed) extracts could be explored in the management oxidative stress-induced degenerative disease such as diabetes and hypertension. The report of this study is in line with previous studies indicating the ability of the phenolic compounds to chelate and/or deactivate transition metals and prevent such metals from participating in the initiation of lipid peroxidation and oxidative stress through metal catalysed reaction $[4,27,38]$. The pericarp from the fruit also exerted the highest $\mathrm{Fe}^{2+}$ chelating ability. This is further buttressed by the agreement between the antioxidant properties of the various Soursop fruit extracts and their phenolic contents.

Recently, polyphenolic compounds have become subjects of interest because of their beneficial effects on human health [26-28]. Numerous studies have shown that majority of the antioxidant activity of plants food is from phenolic compounds such as flavonoids, isoflavones, flavones, anthocyanins, catechin, and isocatechin rather than from vitamins $\mathrm{C}$ and $\mathrm{E}$ and $\beta$-carotene $[27,39,40]$ and is believed to be due to their redox properties [41], which play a crucial role in adsorbing and neutralizing free radicals, quenching singlet and triplet oxygen, decomposing peroxides, chelating metal catalysts, and activating antioxidant enzymes [42]. According to Jiménez et al. [43], about sixteen phenolic compounds were reported to be predominantly present in Soursop fruit pulp. Cinnamic acid derivatives, $\mathrm{p}$-coumaric acids together with several other minor compounds, were identified as the major phenolic compounds in Soursop fruit [43]. However, this study suggests that these phenolics may be well distributed in all the Soursop fruit part. Thus, this study showed that the pericarp had the highest total phenol content, followed by the pulp while the seed had the least phenolic contents (Table 2). This study further revealed that there are strong correlations between the phenolics contents and the biological activities studied. Therefore, phenolics (Table 2) in the Soursop fruit parts (pericarp, pulp, and seed) may be part of the active compound responsible for the antioxidant, antidiabetic, and antihypertensive and may provide a scientific basis of their use in folklore medicine. It is worth noting that the higher phenolic contents in the pericarp compared to the pulp and seed of the fruit could be due to the fact that the pericarp is more exposed to the environmental stress factors such as ultraviolet ray from the sunlight [44]. Stress factors provoke intense synthesis of phenolic compounds in the plant in order to forestall oxidative damage where the stress factors could confer to the plant cellular structures [45], unlike the pulp and seed that are protected by the edible portion of the fruit and therefore have less exposure to such stress factors. However, the values obtained for the extracts are lower than what was reported in some edible plant obtained in Iran and India [46] but higher than phenolics content in some selected tropical fruits from Malaysia [47]. To the best of our knowledge, this is the first time that the phenolic distribution and biological effects of Soursop fruit parts (pericarp, pulp, and seed) were reported. 


\section{Conclusion}

This research investigated and revealed that Soursop fruit extracts possess antioxidant properties and were able to inhibit key enzymes relevant to type- 2 diabetes mellitus ( $\alpha$ amylase and $\alpha$-glucosidase) and hypertension (angiotensinI converting enzyme) in vitro. The antidiabetic, antihypertensive, and antioxidant properties of the fruits part were strongly correlated to the phenolic contents. The combined enzyme inhibitory and antioxidant properties could be part of the biochemical rationale behind the traditional use of the Soursop fruit in the prevention and management of diabetes and hypertension. Nevertheless, this research has shown that Soursop's pericarp had the highest enzyme inhibitory and antioxidant properties compared to other parts (pulp and seed).

\section{Conflict of Interests}

The authors declare that there is no conflict of interests regarding the publication of this paper.

\section{References}

[1] F. Aguiree, A. Brown, N. H. Cho et al., IDF Diabetes Atlas, 2013.

[2] S. Wild, G. Roglic, A. Green, R. Sicree, and H. King, "Global prevalence of diabetes: estimates for the year 2000 and projections for 2030," Diabetes Care, vol. 27, no. 5, pp. 1047-1053, 2004.

[3] T. H. W. Huang, G. Peng, B. P. Kota et al., "Anti-diabetic action of Punica granatum flower extract: activation of PPAR- $\gamma$ and identification of an active component," Toxicology and Applied Pharmacology, vol. 207, no. 2, pp. 160-169, 2005.

[4] A. Abirami, G. Nagarani, and P. Siddhuraju, "In vitro antioxidant, anti-diabetic, cholinesterase and tyrosinase inhibitory potential of fresh juice from Citrus hystrix and C. maxima fruits," Food Science and Human Wellness, vol. 3, no. 1, pp. 16-25, 2014.

[5] G. L. Bakris, M. Williams, L. Dworkin et al., "Preserving renal function in adults with hypertension and diabetes: a consensus approach," American Journal of Kidney Diseases, vol. 36, no. 3, pp. 646-661, 2000.

[6] M. F. McCarty, "ACE inhibition may decrease diabetes risk by boosting the impact of bradykinin on adipocytes," Medical Hypotheses, vol. 60, no. 6, pp. 779-783, 2003.

[7] A. Wélé, Y. Zhang, C. Caux, J.-P. Brouard, J.-L. Pousset, and B. Bodo, "Annomuricatin C, a novel cyclohexapeptide from the seeds of Annona muricata," Comptes Rendus Chimie, vol. 7, no. 10-11, pp. 981-988, 2004.

[8] C. Gleye, A. Laurens, R. Hocquemiller, O. Laprévote, L. Serani, and A. Cavé, "Cohibins A and B, acetogenins from roots of Annona muricata," Phytochemistry, vol. 44, no. 8, pp. 1541-1545, 1997.

[9] S. Gajalakshmi, S. Vijayalakshmi, and R. V. Devi, "Phytochemical and pharmacological properties of Annona muricata: a review," International Journal of Pharmacy and Pharmaceutical Sciences, vol. 4, no. 2, pp. 3-6, 2012.

[10] S. A. Adefegha and G. Oboh, "Enhancement of total phenolics and antioxidant properties of some tropical green leafy vegetables by steam cooking," Journal of Food Processing and Preservation, vol. 35, no. 5, pp. 615-622, 2011.
[11] Worthington Biochemical Corporation, Worthington Enzyme and Related Biochemicals, Worthington Biochemical Corporation, Freehold, NJ, USA, 1978.

[12] E. Apostolidis, Y.-I. Kwon, and K. Shetty, "Inhibitory potential of herb, fruit, and fungal-enriched cheese against key enzymes linked to type 2 diabetes and hypertension," Innovative Food Science and Emerging Technologies, vol. 8, no. 1, pp. 46-54, 2007.

[13] D. W. Cushman and H. S. Cheung, "Spectrophotometric assay and properties of the angiotensin-converting enzyme of rabbit lung," Biochemical Pharmacology, vol. 20, no. 7, pp. 1637-1648, 1971.

[14] M. A. Gyamfi, M. Yonamine, and Y. Aniya, "Free-radical scavenging action of medicinal herbs from Ghana: Thonningia sanguinea on experimentally-induced liver injuries," General Pharmacology, vol. 32, no. 6, pp. 661-667, 1999.

[15] R. Re, N. Pellegrini, A. Proteggente, A. Pannala, M. Yang, and C. Rice-Evans, "Antioxidant activity applying an improved ABTS radical cation decolorization assay," Free Radical Biology and Medicine, vol. 26, no. 9-10, pp. 1231-1237, 1999.

[16] B. Halliwell and J. M. C. Gutteridge, "Formation of a thiobarbituric-acid-reactive substance from deoxyribose in the presence of iron salts: the role of superoxide and hydroxyl radicals," FEBS Letters, vol. 128, no. 2, pp. 347-352, 1981.

[17] M. Oyaizu, "Studies on products of browning reaction. Antioxidative activities of products of browning reaction prepared from glucosamine," The Japanese Journal of Nutrition and Dietetics, vol. 44, no. 6, pp. 307-315, 1986.

[18] G. Minotti and S. D. Aust, "An investigation into the mechanism of citrate- $\mathrm{Fe}^{2+}$-dependent lipid peroxidation," Free Radical Biology and Medicine, vol. 3, no. 6, pp. 379-387, 1987.

[19] R. L. Puntel, C. W. Nogueira, and J. B. T. Rocha, "Krebs cycle intermediates modulate thiobarbituric acid reactive species (TBARS) production in rat brain in vitro," Neurochemical Research, vol. 30, no. 2, pp. 225-235, 2005.

[20] V. L. Singleton, R. Orthofer, and R. M. Lamuela-Raventós, "Analysis of total phenols and other oxidation substrates and antioxidants by means of Folin-ciocalteu reagent," Methods in Enzymology, vol. 299, pp. 152-178, 1999.

[21] A. Meda, C. E. Lamien, M. Romito, J. Millogo, and O. G. Nacoulma, "Determination of the total phenolic, flavonoid and proline contents in Burkina Fasan honey, as well as their radical scavenging activity," Food Chemistry, vol. 91, no. 3, pp. 571-577, 2005.

[22] J. H. Zar, Biostatistical Analysis, Prentice Hall, New York, NY, USA, 1984.

[23] S. S. Nair, V. Kavrekar, and A. Mishra, "In vitro studies on alpha amylase and $\alpha$ glucosidase inhibitory activities of selected plant extracts," European Journal of Experimental Biology, vol. 3, no. 1, pp. 128-132, 2013.

[24] S. Banu, N. R. Jabir, N. C. Manjunath et al., "Reduction of post-prandial hyperglycemia by mulberry tea in type-2 diabetes patients," Saudi Journal of Biological Sciences, vol. 22, no. 1, pp. 32-36, 2015.

[25] S. Saravanan and T. Parimelazhagan, "In vitro antioxidant, antimicrobial and anti-diabetic properties of polyphenols of Passiflora ligularis Juss, fruit pulp," Food Science and Human Wellness, vol. 3, no. 2, pp. 56-64, 2014.

[26] S. A. Adefegha and G. Oboh, "Inhibition of key enzymes linked to type 2 diabetes and sodium nitroprusside-induced lipid peroxidation in rat pancreas by water extractable phytochemicals from some tropical spices," Pharmaceutical Biology, vol. 50, no. 7, pp. 857-865, 2012. 
[27] A. O. Ademiluyi, G. Oboh, F. P. Aragbaiye et al., "Antioxidant properties and in vitro $\alpha$-amylase and $\alpha$-glucosidase inhibitory properties of phenolics constituents from different varieties of Corchorus spp.", Journal of Taibah University Medical Sciences, vol. 10, no. 3, pp. 278-287, 2015.

[28] S. A. Adefegha, G. Oboh, O. M. Adefegha, A. A. Boligon, and M. L. Athayde, "Antihyperglycemic, hypolipidemic, hepatoprotective and antioxidative effects of dietary clove (Szyzgium aromaticum) bud powder in a high-fat diet/streptozotocininduced diabetes rat model," Journal of the Science of Food and Agriculture, vol. 94, no. 13, pp. 2726-2737, 2014.

[29] Q.-L. Li, B.-G. Li, Y. Zhang, X.-P. Gao, C.-Q. Li, and G.-L. Zhang, "Three angiotensin-converting enzyme inhibitors from Rabdosia coetsa," Phytomedicine, vol. 15, no. 5, pp. 386-388, 2008.

[30] L. G. Ranilla, Y.-I. Kwon, E. Apostolidis, and K. Shetty, "Phenolic compounds, antioxidant activity and in vitro inhibitory potential against key enzymes relevant for hyperglycemia and hypertension of commonly used medicinal plants, herbs and spices in Latin America, Bioresource Technology, vol. 101, no. 12, pp. 4676-4689, 2010.

[31] G. Oboh, A. O. Ademiluyi, A. J. Akinyemi, T. Henle, J. A. Saliu, and U. Schwarzenbolz, "Inhibitory effect of polyphenolrich extracts of jute leaf (Corchorus olitorius) on key enzyme linked to type 2 diabetes ( $\alpha$-amylase and $\alpha$-glucosidase) and hypertension (angiotensin I converting) in vitro," Journal of Functional Foods, vol. 4, no. 2, pp. 450-458, 2012.

[32] M. Umamaheswari, M. P. Ajith, K. Asokkumar, T. Sivashanmugam, V. Subhadradevi, and P. Jagannath, "In vitro angiotensin converting enzyme inhibitory and antioxidant activities of methanolic seed extract of Apium graveolens Linn," Journal of Pharmaceutical and Allied Sciences, vol. 8, no. 3, pp. 1400-1410, 2011.

[33] M. Brownlee, "The pathobiology of diabetic complications: a unifying mechanism," Diabetes, vol. 54, no. 6, pp. 1615-1625, 2005.

[34] E. L. Schiffrin, "Antioxidants in hypertension and cardiovascular disease," Molecular Interventions, vol. 10, no. 6, pp. 354-362, 2010.

[35] H. Yoshida and S. Takagi, "Antioxidative effects of sesamol and tocopherols at various concentrations in oils during microwave heating," Journal of the Science of Food and Agriculture, vol. 79, no. 2, pp. 220-226, 1999.

[36] L. Yu, S. Haley, J. Perret, M. Harris, J. Wilson, and M. Qian, "Free radical scavenging properties of wheat extracts," Journal of Agricultural and Food Chemistry, vol. 50, no. 6, pp. 1619-1624, 2002.

[37] H. Bayir, P. M. Kochanek, and V. E. Kagan, "Oxidative stress in immature brain after traumatic brain injury," Developmental Neuroscience, vol. 28, no. 4-5, pp. 420-431, 2006.

[38] G. Oboh, A. J. Akinyemi, A. O. Ademiluyi, and S. A. Adefegha, "Inhibitory effects of aqueous extracts of two varieties of ginger on some key enzymes linked to type-2 diabetes in vitro," Journal of Food and Nutrition Research, vol. 49, no. 1, pp. 14-20, 2010.

[39] A. Marín, F. Ferreres, F. A. Tomás-Barberán, and M. I. Gil, "Characterization and quantitation of antioxidant constituents of sweet pepper (Capsicum annuum L.)," Journal of Agricultural and Food Chemistry, vol. 52, no. 12, pp. 3861-3869, 2004.

[40] Y.-F. Chu, J. Sun, X. Wu, and R. H. Liu, "Antioxidant and antiproliferative activities of common vegetables," Journal of Agricultural and Food Chemistry, vol. 50, no. 23, pp. 6910-6916, 2002.
[41] M. M. Islam, "Biochemistry, medicinal and food values of Jute (Corchorus capsularis L and C. olitorius L) leaf: a review," International Journal of Enhanced Research in Science Technology and Engineering, vol. 2, no. 11, pp. 35-44, 2013.

[42] S. R. V. Jaya and R. G. Deval, "Evaluation of in vitro \& in vivo antioxidant studies of whole plant of $70 \%$ ethanolic extracts of Indigofera Barberi Gambles," International Journal of Innovative Pharmaceutical Research, vol. 5, no. 1, pp. 378-388, 2014.

[43] V. M. Jiménez, M. Gruschwitz, R. M. Schweiggert, R. Carle, and P. Esquivel, "Identification of phenolic compounds in soursop (Annona muricata) pulp by high-performance liquid chromatography with diode array and electrospray ionization mass spectrometric detection," Food Research International, vol. 65, pp. 42-46, 2014.

[44] K. Soumaya, F. Chaouachi, R. Ksouri, and M. El-Gazzah, "Polyphenolic composition in different organs of Tunisia populations of Cynara cardunculus L and their antioxidant activity," Journal of Food and Nutrition Research, vol. 1, no. 1, pp. 1-6, 2013.

[45] A. Chanwitheesuk, A. Teerawutgulrag, and N. Rakariyatham, "Screening of antioxidant activity and antioxidant compounds of some edible plants of Thailand," Food Chemistry, vol. 92, no. 3, pp. 491-497, 2005.

[46] A. Aberoumand and S. S. Deokule, "Total phenolic contents of some plant foods as a antioxidant compound," Journal of Food Technology, vol. 8, no. 3, pp. 131-133, 2010.

[47] M. Alothman, R. Bhat, and A. A. Karim, "Antioxidant capacity and phenolic content of selected tropical fruits from Malaysia, extracted with different solvents," Food Chemistry, vol. 115, no. 3, pp. 785-788, 2009. 

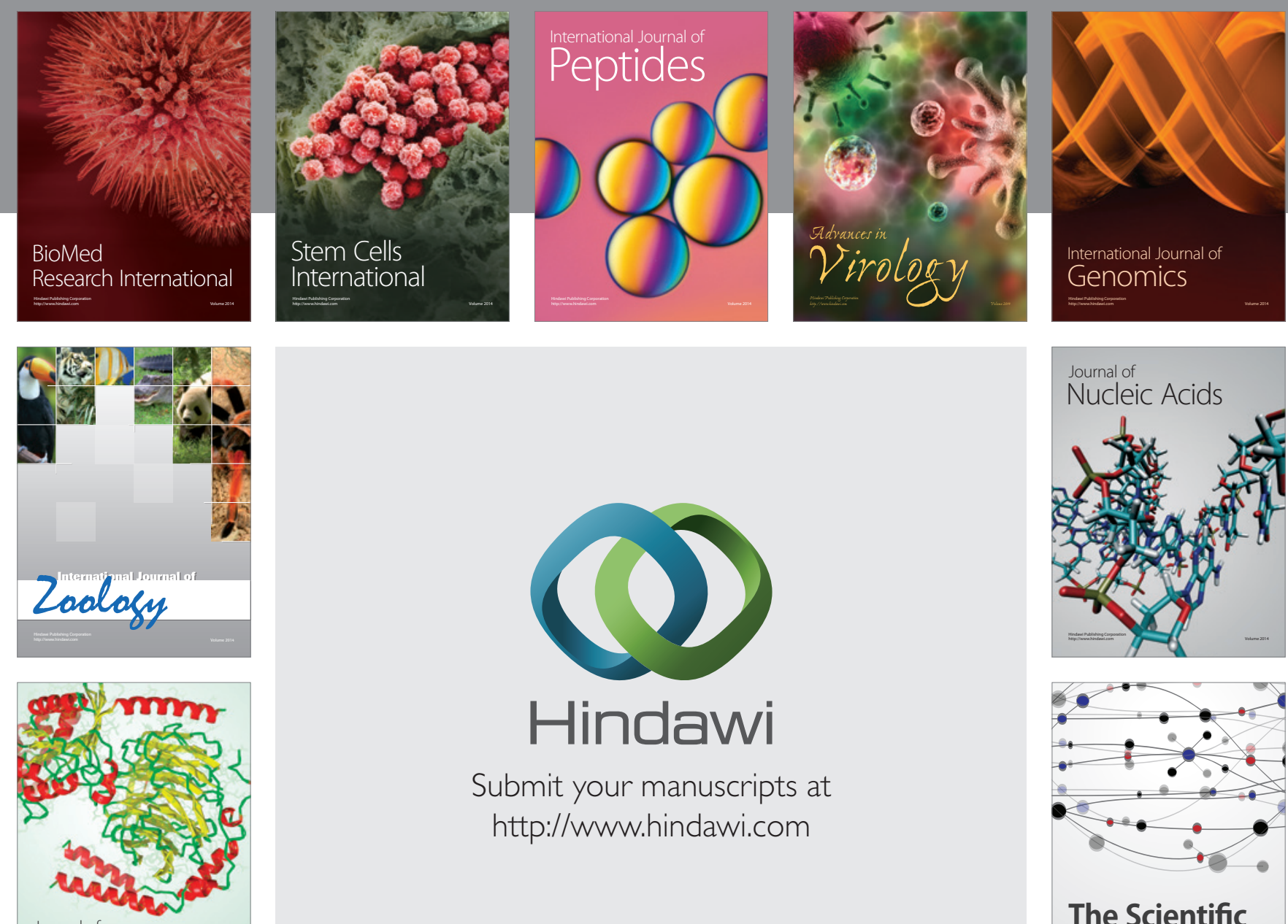

Submit your manuscripts at

http://www.hindawi.com

Journal of
Signal Transduction
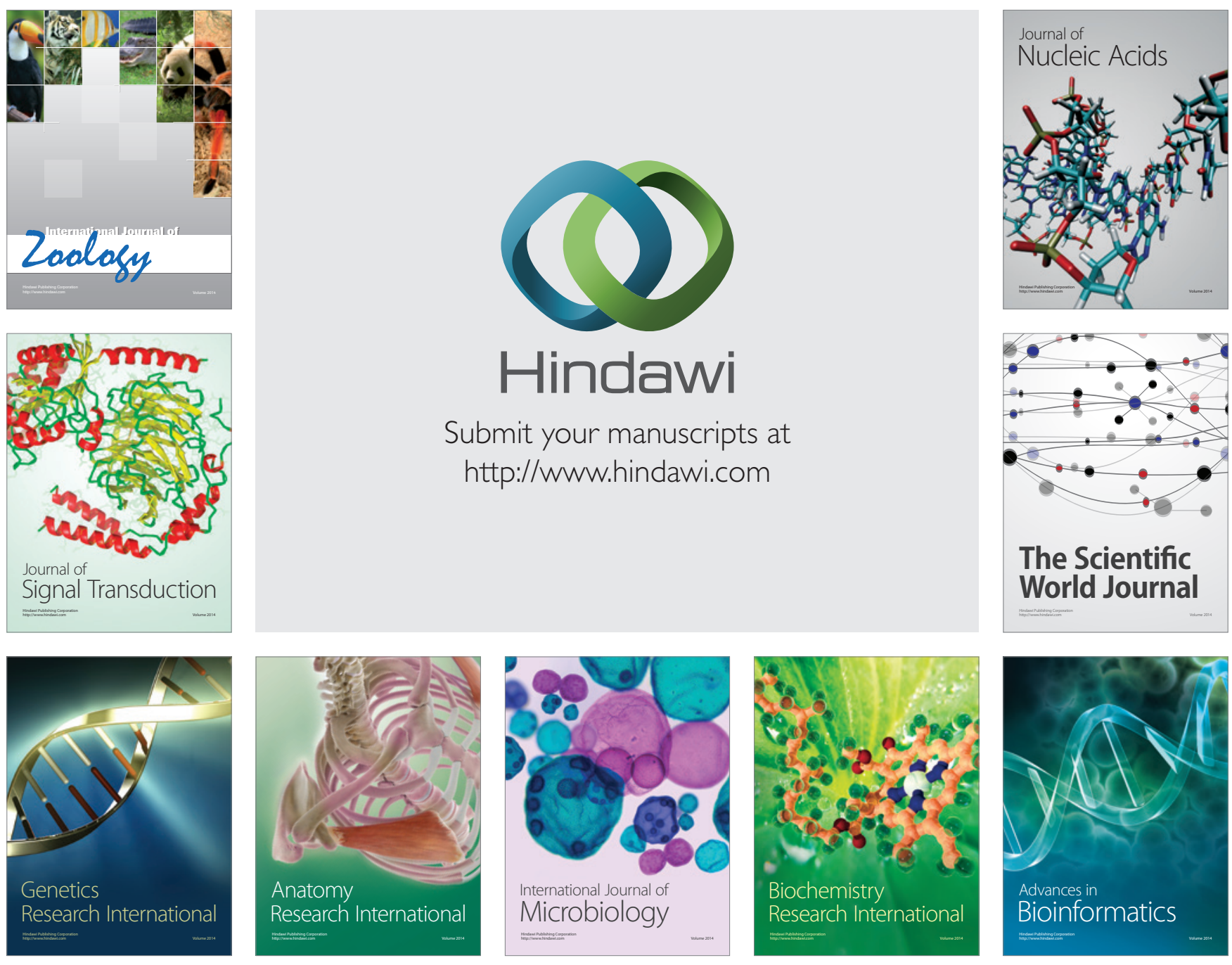

The Scientific World Journal
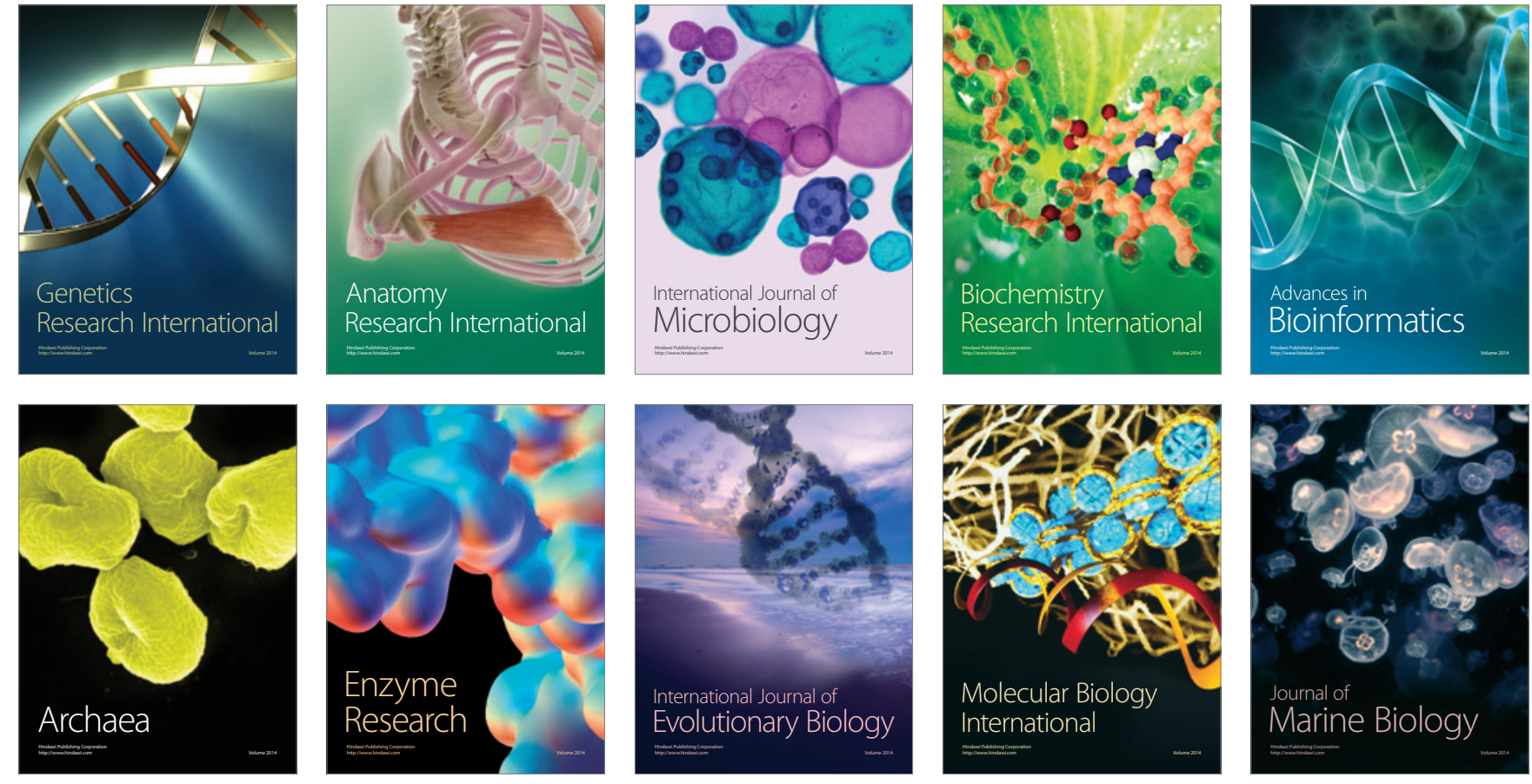